\title{
Učinak liječenja osteoartritisa koljenskog zgloba primjenom matičnih stanica - rani rezultati
}

\section{The effect of treatment of knee joint osteoarthritis using stem cells - early results}

\author{
Vjeran Rapan, Domagoj Rapan, Saša Rapan*
}

\begin{abstract}
Sažetak. Cilj: Svrha istraživanja bila je ispitati učinkovitost liječenja osteoartritisa koljenskoga zgloba uporabom matičnih stanica. Ispitanici i metode: $U$ ispitivanje je bilo uključeno 10 pacijenata s artrozom drugog stupnja, koji su operirani u Odjelu za ortopediju Kliničkog bolničkog centra Osijek. Prijeoperacijski pacijenti obrađeni su standardnom radiološkom snimkom koljena, te uz pomoć MRI-ja. Graft dobiven liposukcijom centrifugiran je i pomiješan s plazmom bogatom trombocitima (PRP) te je potom apliciran u oboljeli zglob. Tri mjeseca nakon procedure s pacijentima smo telefonski kontaktirali, a dobiveni podaci su statistički obrađeni. Rezultati: Nakon 3 mjeseca od aplikacije matičnih stanica u koljenski zglob postoji statistički značajno poboljšanje ako se prati oteklina zgloba, bol pri stajanju na mjestu, bol pri hodanju po ravnoj podlozi, bol pri hodanju uz stepenice. Zaključci: lako je naše istraživanje provedeno na malom broju ispitanika, a vrijeme praćenja bilo relativno kratko, pacijenti su pokazali značajno funkcionalno poboljšanje kliničkih tegoba. Potrebna su daljnja istraživanja i praćenja kako bi se donijele smjernice u liječenju ovom metodom, dužim praćenjem i većim brojem ispitanika.
\end{abstract}

Ključne riječi: liječenje; matična stanica; osteoartritis

\begin{abstract}
Aim: The purpose of the study was to examine the efficacy of treating osteoarthritis of the knee joint using stem cells. Patients and Methods: The study included 10 patients with second-degree arthrosis, who were operated on at the Department of Orthopedics, Clinical Hospital Center Osijek. Preoperative patients were treated with the standard radiological knee imaging and MRI. The graft obtained by liposuction was centrifuged and mixed with platelet rich plasma (PRP), and was then applied to the diseased joint. Three months after the procedure, patients were contacted by phone and the data obtained was statistically processed. Results: After 3 months of application of stem cells to the knee joint, a statistically significant improvement occurred if joint swelling is observed, the pain while standing, walking on a flat surface and walking up the stairs. Conclusions: Although our study was conducted on a small number of subjects and the time was relatively short, the patients showed a significant functional improvement in clinical troubles. A further research and follow-up are needed to provide the treatment guidelines for this method, using a longer follow-up, and more subjects.
\end{abstract}

Key words: osteoarthritis; stem cell; treatment

medicina fluminensis 2020 , Vol. 56 , No. 3, p. 307-314
Medicinski fakultet, Sveučilište u Osijeku, Osijek

*Dopisni autor:

Izv. prof. dr. sc. Saša Rapan,

Medicinski fakultet Sveučilišta u Osijeku,

J. Huttlera 4, 31000 Osijek

E-mail: sasa.rapan@gmail.com

http://hrcak.srce.hr/medicina 


\section{UVOD}

Osteoartritis (OA) je degenerativna bolest zglobova koja uglavnom zahvaća zglobnu hrskavicu i subhondralnu kost. Za OA je dostupno nekoliko opcija liječenja, konzervativno ili operativno, s različitim prednostima i rizicima ${ }^{1-11}$. Regenerativne stanice kao što su matične stanice odraslih iz masnog tkiva (ASC, matične stanice dobivene iz masnog tkiva) koriste se u kombinaciji s PRP-om (plazmom obogaćenom trombocitima) (ACP).

Među mnogim potencijalnim područjima primjene terapije matičnim stanicama masnih kiselina, liječenje degenerative bolesti poput osteoartritisa (OA) aktualna je tema.
Daljnja prednost za kliničku primjenu je laka dostupnost i obilje ASC-a.

Oni su dio stromalne vaskularne frakcije (SVF), to se lako i učinkovito mogu izolirati i brzo iz masnog tkiva liposukcijom i slijedećom obradom aspirata. Tehnika se temelji na mehaničkoj disocijaciji odlaska zrelih adipocita iza peletiziranog SVF-a. Rezultirajući SVF pellet sastoji se od heterogene stanične populacije. Pored ASC-a uključuju i hematopoetske stanice, pre-adipocite, periciti, endotelne i progenitorne stanice 5 . Do sad je u nekoliko in vivo studija, koristeći životinjsku i staničnu kulturu modela, dokazana sigurnost, kao i imunosupresivna, antioksidativna, antiapoptotska i angiogena svojstva SVF stanica i ASC-ovi ${ }^{12,13}$. Zbog mogućeg regenerativnog potencijala prvi pretklinički i klinički testovi za liječenje osteoartritisa autolognim SVF-om daju pozitivne rezultate.

Kako bi se dodatno poboljšala učinkovitost liječenja SVF/ASC, novi je pristup kombinirati in s plazmom bogatom trombocitima siromašnom leukocitima (PRP). Dobiva se PRP siromašan leukocitima i crvenim krvnim zrncima, a količina trombocita je koncentrirana.

Time se obogaćuju faktori rasta koje oslobađaju trombociti. Kombinacijom ASC-a s PRP siromašnim leukocitima hipotetiramo da se broj injekcija može smanjiti i klinički se ishod može još poboljšati. Neka in vitro i pretklinička ispitivanja pokazala su da PRP i ASC imaju sinergistički učinak. To se može tumačiti da PRP potiče staničnu proliferaciju i razlikovanje matičnih stanica dobivenih iz masnog tkiva u različitim tkivima poput hrskavice, kostiju i kožž ${ }^{14-17}$.

U usporedbi sa stanicama dobivenim iz koštane srži, stanice dobivene iz masnog tkiva su genetički stabilnije, imaju viši kapacitet proliferacije i diferencijacije, imaju manji omjer starijih stanica i duže telomere ${ }^{18}$.

Mehanizam djelovanja nije do kraja razjašnjen. Prvi mogući mehanizam je sekretorni efekt matičnih stanica. Drugi mogući mehanizam je direktna ugradnja i diferencijacija stanica na oštećenom tkivu. Treći i najvjerojatniji mehanizam je kombinacija ugradnje matičnih stanica na oštećeno tkivo i sekretorni efekt tih stanica ${ }^{17}$.

Matične stanice imaju tzv. „homing effect“. Kada se injiciraju u domaćina, migriraju do željenog mjesta pute različitih kemokinskih receptora poput CXR4, integrina, selektina (engl. vascular cell adhesion molecule-1) itd. ${ }^{19}$

Broj stanica koje se mogu dobiti iz jednog grama masnog tkiva varira između 5000 i 200000 stanica. Upravo zbog te razlike postoji i različit terapijski odgovor kod pacijenata, jer što je veći broj matičnih stanica u uzorku veća je hrskavična regeneracija ${ }^{17}$.

\section{ISPITANICI I METODE}

\section{Ispitanici}

Podaci u ovom istraživanju korišteni su iz dokumentacije koju su pacijenti donijeli sa sobom prije operacijskog zahvata, radioloških snimaka i snimaka MRI koljena, uzimanjem anamneze pri dolasku i kliničkog nalaza, a poslijeoperacijski rezultati prikupljeni su telefonski; prikupio ih je liječnik specijalizant u Odjelu za ortopediju KBC-a Osijek.

Pacijenti su dali usmeni pristanak za prikupljanje podataka i sudjelovanje u istraživanju, za koje nismo tražili odobrenje etičkog povjerenstva. $U$ trenutku pristupanja operacijskoj proceduri svi pacijenti su potpisali formular pristanka na proceduru i suglasnost s njom.

U periodu od listopada 2019. do ožujka 2020. godine liječili smo 10 pacijenata s osteoartritisom koljenskog zgloba, drugog stupnja po Kelllgren Lawrenceu, u dobi između 22 i 59 godina, s 
ACPSVF aplikacijom lijeka intraartikularno, bez artroskopske intervencije. Radiološki 2. stupanj artroze po Kellgren Lawrencu ${ }^{20}$ bio je najvažniji čimbenik pri selekciji pacijenata. Ako bi pacijent zadovoljio ovaj kriterij, dodatno je rađena magnetska rezonancija (MR) kako bi se evidentirale promjene hrskavičnog tkiva, te eventualno lezije meniska ili ligamenata. Kod svih pacijenata koji su odabrani za navedenu proceduru provedeno je uobičajeno konzervativno liječenje medikamentima i fizikalnim procedurama, bez značajnijeg uspjeha.

\section{Metode}

Za mjerenje intenziteta pacijentova bola koristili smo uobičajenu VAS skalu (Vizualna analogna ljestvica bola). VAS skala kreće se od 0 do 10, u kojoj 10 odražava maksimalnu bolnost, a 0 bezbolnost. Pacijenti su bili pitani za intenzitet bola prije, kao i nakon procedure, minimalno dva tjedna nakon procedure.

Pacijenti su ocijenjeni tijekom tri mjeseca vremenskog razdoblja nakon terapije u smislu bola, pokretljivosti i fizičke funkcionalnosti VAS ljestvicom.

\section{Operacijska tehnika}

Za proizvodnju stromalne vaskularne frakcije (SVF-a), set za uzimanje masnog potkožnog tkiva korišten je u kompletu u kombinaciji s ACP dvostrukim štrcaljkama.

Za liposukciju $30 \mathrm{ml}$ fiziološke otopine s adrenalinom, odgovarajućeg omjera, infiltrirano je u ciljano područje (ili trbušnu stijenku ili bedro) uz prethodno kirurško pranje i pokrivanje operacijskog polja (slika 1).

Nakon razdoblja čekanja od $15 \mathrm{~min}, 30 \mathrm{ml}$ masnog tkiva je spravljeno u 2 ACP dvostruke šprice, po $15 \mathrm{ml}$, koristeći kanilu za prikupljanje, iz kompleta za skupljanje tkiva Adipose. Obje ACP dvostruke štrcaljke su centrifugirane tijekom 4 minute pri 2.500 o/min u odgovarajućoj centrifugi, što rezultira u troslojnom odvajanju lipoaspirata. Koristeći se principom dvostruke šprice (slika 2), ulje i vodene frakcije su uklonjene, a masni je graf zaostao (slika 3).

Graft je procijeđen najmanje 30 puta kroz uređaj za navlačenje za mehaničku disocijaciju adipocita. Nakon drugog centrifugiranja pri $2.500 \mathrm{o} / \mathrm{min}$

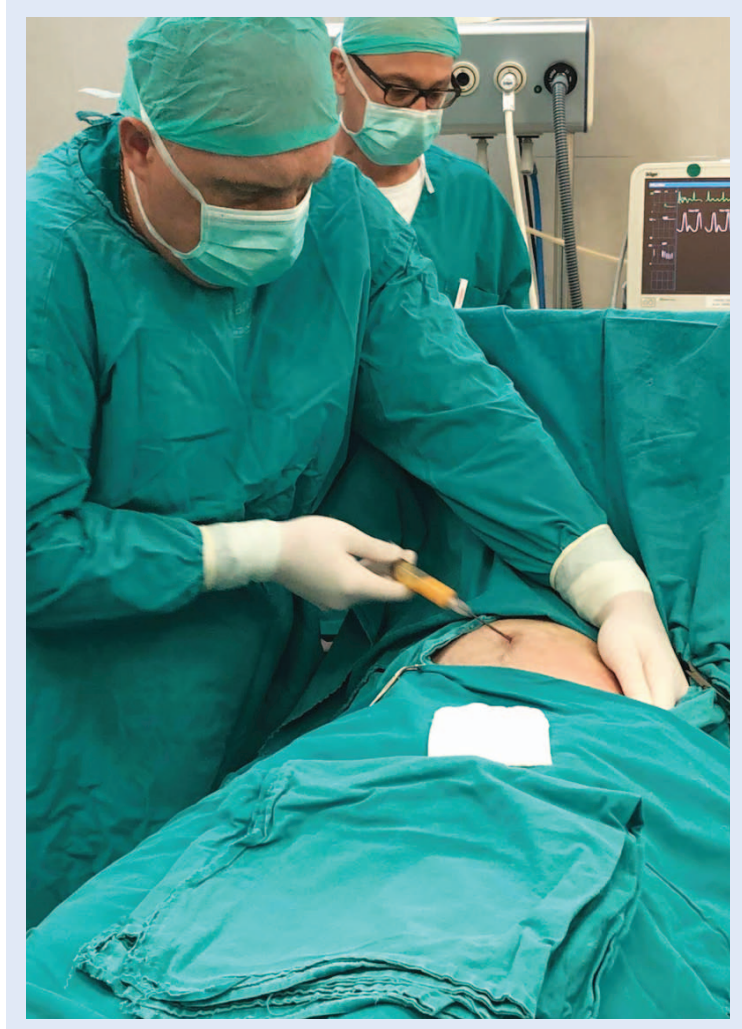

Slika 1. Liposukcija

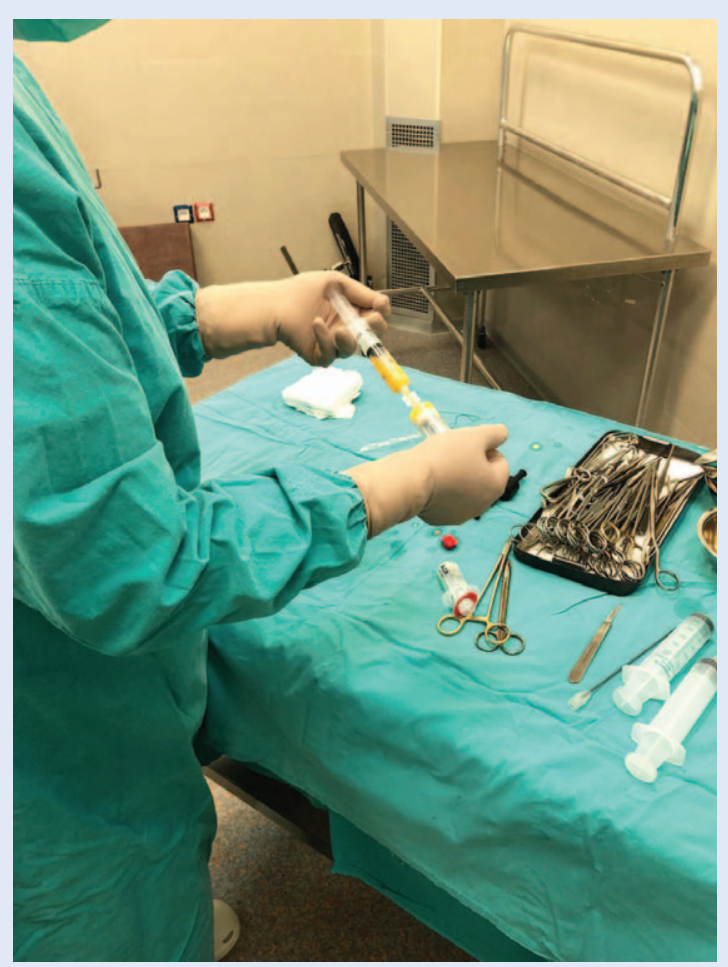

Slika 2. Odvajanje ulja i vodene frakcije 


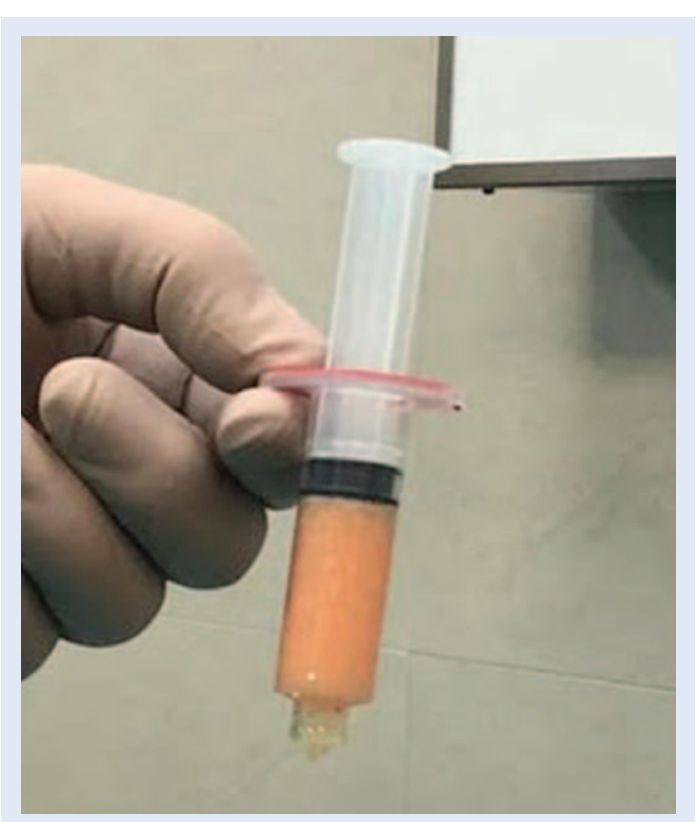

Slika 3. Masni graft

Unatoč maloj skupini ispitanika i kratkom praćenju, naši rezultati govore da je primjena matičnih stanica masnih kiselina učinkovita u olakšavanju bola i funkcionalnom poboljšanju kod osteoartritisa koljena.

4 minute odvojeno ulje uklonjeno je napuštajući SVF u ACP dvostrukoj štrcaljki.

Za proizvodnju ACP-a $15 \mathrm{ml}$ venske krvi povučeno je izravno u ACP dvostruku štrcaljku i centrifugirano 5 minuta pri 1.500 o/min pomoću centrifuge Rotofix 32A. Nakon postupka centrifugiranja, ACP je prebačen iz veće vanjske štrcaljke u malu unutarnju štrcaljku. Prije upotrebe mali unutarnji špric je odvijen i ACP je bio spreman za upotrebu. Nakon toga ACPSVF stvorio je ponovno suspendiranje SVF stanične pelete u ACP (slika 3). Injekcije su izvedene standardnom tehnikom intraartikularnog ubrizgavanja.

\section{Statistika}

Analiza podataka provedena je u programskom paketu: PS Imago PRO (IBM SPSS Statistics 26.0), a statističke testove koje smo koristili su Wilcoxonov test i McNemar Test.

Wilcoxonov test smo koristili kako bismo ustanovili razliku u ponovljenim mjerenjima kod promatranih pacijenata. Za ovaj neparametrijski test odlučili smo se zato što je relativno malen broj is- pitanika uključen u uzorak. Test McNemar koristili smo kako bismo utvrdili jesu li rubne frekvencije retka i stupca jednake (to jest, postoji li „granična homogenost").

\section{REZULTATI}

U našem istraživanju 70,0 \% ispitanika je muškog spola, dok je 30,0 \% ispitanika ženskog spola.

Pogledaju li se podatci za dob ispitanika može se uočiti kako medijan dobi iznosi 45,00 godina (interkvartilnog raspona od 36,25 do 54,25 godina). $50,0 \%$ ispitanika ima $22-45$ godina, dok 50,0\% ima 46 i više godina.

U tablici 1 prikazani su podatci vezani za vrijeme proteklo od operacijskog zahvata (tablica 1).

Kod svih promatranih pacijenata dijagnosticiran je 2. stupanj artroze.

Raniji operacijski zahvat imalo je 60,0\% ispitanika, dok nije ranije operirano 40,0\% ispitanika.

Vrste operacijskih procedura na koljenskom zglobu prikazane su u tablici 2 (tablica 2).

Deskriptivni podatci odgovora ispitanika za prvo i drugo mjerenje, vrijednost aritmetičke sredine, standardne devijacije te minimalna i maksimalna vrijednost za sve promatrane varijable prikazani su u posebnoj tablici (tablica 3).

Rangovi odgovora ispitanika kad su u pitanju rezultati za prvo i drugo mjerenje, prikazani su u tablici 4 (tablica 4). Na temelju toga može se uočiti kako je za oteklinu u 5 slučajeva zabilježen negativan rang, odnosno vrijednost pokazatelja na posttestiranju je manja od vrijednosti odgovora na inicijalnom testiranju, dok je u 0 slučajeva zabilježen pozitivan rang, odnosno vrijednost odgovora na posttestiranju veća je od vrijednosti odgovora na inicijalnom testiranju, najzad, u 5 slučajeva zabilježena je jednaka vrijednost odgovora i za inicijalno i za postoperacijsko testiranje.

Gledajući rangove za pokretljivost u 1 slučaju zabilježen je negativan rang, odnosno vrijednost pokazatelja na postoperacijskom testiranju manja je od vrijednosti odgovora na inicijalnom testiranju, dok je u 4 slučaja zabilježen pozitivan rang, odnosno vrijednost odgovora na posttestiranju veća je od vrijednosti odgovora na inicijalnom testiranju; najzad, u 5 slučajeva zabilježena je jednaka vrijednost odgovora i za inicijalno i za postoperacijsko testiranje. 
Tablica 1. Vrijeme nakon prethodne operacijske procedure (dani)

\begin{tabular}{|c|c|c|c|}
\hline & & $\mathrm{N}$ & $\%$ \\
\hline \multirow{3}{*}{ Vrijeme prošlo od operacije (dana) } & $14-50$ dana & 6 & 60,0 \\
\hline & 51 i više dana & 4 & 40,0 \\
\hline & Ukupno & 10 & 100,0 \\
\hline
\end{tabular}

Tablica 2. Vrsta ranijeg operacijskog zahvata

\begin{tabular}{|l|l|c|}
\hline \multirow{5}{*}{ Vrsta op. zahvata } & Nije operiran & N \\
\hline & Artroskopija & 4 \\
\hline & Artroskopska toaleta & 1 \\
\hline & Osteosinteza & 2 \\
\hline & Rekonstrukcija LCA-a & 1 \\
\hline & Rekonstrukcija LCA-a, menisektomija & 1 \\
\hline
\end{tabular}

Tablica 3. Deskriptivni pokazatelji funkcionalnog statusa koljena

\begin{tabular}{|l|l|l|l|c|c|}
\hline & N & $\overline{\mathbf{x}}$ & Sd & Min & Maks \\
\hline Oteklina preop. & 10 & 3,60 & 2,171 & 1 & 8 \\
\hline Pokretljivost preop & 10 & 7,10 & 2,132 & 4 & 10 \\
\hline Bol pri ležanju preop. & 10 & 3,10 & 2,644 & 1 & 8 \\
\hline Bol pri stajanju na mjestu preop. & 10 & 4,10 & 2,424 & 1 & 8 \\
\hline Bol pri hodanju po ravnoj podlozi preop. & 10 & 4,70 & 2,163 & 1 & 8 \\
\hline Bol pri hodanju uz stepenice preop. & 10 & 6,00 & 2,828 & 1 & 9 \\
\hline Bol trbuha 1. postop. dan & 10 & 4,30 & 2,584 & 1 & 9 \\
\hline Oteklina postop. & 10 & 2,20 & 1,229 & 1 & 4 \\
\hline Pokretljivost postop. & 10 & 8,20 & 1,229 & 7 & 10 \\
\hline Bol pri ležanju postop. & 10 & 1,60 & 1,350 & 1 & 5 \\
\hline Bol pri stajanju na mjestu postop. & 10 & 2,60 & 2,413 & 1 & 7 \\
\hline Bol pri hodanju po ravnoj podlozi postop. & 10 & 2,00 & 1,414 & 1 & 5 \\
\hline Bol pri hodanju uz stepenice postop. & 10 & 3,10 & 2,685 & 1 & 8 \\
\hline Bol trbuha danas & 10 & 1,20 & 0,422 & 1 & 2 \\
\hline
\end{tabular}

Pogledaju li se rangovi za bol pri ležanju, u 4 slučajeva zabilježen je negativan rang, odnosno vrijednost pokazatelja na posttestiranju manja je od vrijednosti odgovora na inicijalnom testiranju, dok je u 0 slučajeva zabilježen pozitivan rang, odnosno vrijednost odgovora na posttestiranju veća je od vrijednosti odgovora na inicijalnom testiranju; najzad, u 6 slučajeva zabilježena je jednaka vrijednost odgovora i za inicijalno i za postoperacijsko testiranje.

U rangu bol pri stajanju na mjestu u 6 slučajeva zabilježen je negativan rang, odnosno vrijednost pokazatelja na postoperacijskom testiranju manja je od vrijednosti odgovora na inicijalnom testiranju, dok je u 0 slučajeva zabilježen pozitivan rang, odnosno vrijednost odgovora na postoperacijskom testiranju veća je od vrijednosti odgovora na inicijalnom testiranju; najzad, u 4 slučaja zabilježena je jednaka vrijednost odgovora i za inicijalno i za postoperacijsko testiranje.

Za bol pri hodanju po ravnoj podlozi u 9 slučajeva zabilježen je negativan rang, odnosno vrijednost pokazatelja na postoperacijskom testiranju manja je od vrijednosti odgovora na inicijalnom testiranju, dok je u 0 slučajeva zabilježen pozitivan rang, odnosno vrijednost odgovora na postoperacijskom testiranju veća je od vrijednosti odgovora na inicijalnom testiranju, najzad, u jednom slučaju zabilježena je jednaka vrijednost odgovora i za inicijalno i za postoperacijsko testiranje.

Za bol pri hodanju uz stepenice u 8 slučajeva zabilježen je negativan rang, odnosno vrijednost pokazatelja na postoperacijskom testiranju manja je od vrijednosti odgovora na inicijalnom testiranju, 
Tablica 4. Rangovi funkcionalnih nalaza

\begin{tabular}{|c|c|c|c|c|}
\hline & & $\mathbf{N}$ & $\begin{array}{c}\text { Aritmetička } \\
\text { sredina rangova }\end{array}$ & $\begin{array}{c}\text { Suma } \\
\text { rangova }\end{array}$ \\
\hline \multirow{4}{*}{ Oteklina postop. - Oteklina preop. } & Negativni rangovi & $5^{a}$ & 3,00 & 15,00 \\
\hline & Pozitivni rangovi & $0^{\mathrm{b}}$ & 0,00 & 0,00 \\
\hline & Jednako & $5^{c}$ & & \\
\hline & Ukupno & 10 & & \\
\hline \multirow{4}{*}{ Pokretljivost postop. - Pokretljivost preop } & Negativni rangovi & $1^{\mathrm{a}}$ & 1,00 & 1,00 \\
\hline & Pozitivni rangovi & $4^{b}$ & 3,50 & 14,00 \\
\hline & Jednako & $5^{c}$ & & \\
\hline & Ukupno & 10 & & \\
\hline \multirow{4}{*}{ Bol pri ležanju postop. - Bol pri ležanju preop. } & Negativni rangovi & $4^{\mathrm{a}}$ & 2,50 & 10,00 \\
\hline & Pozitivni rangovi & $0^{\mathrm{b}}$ & 0,00 & 0,00 \\
\hline & Jednako & $6^{c}$ & & \\
\hline & Ukupno & 10 & & \\
\hline \multirow{4}{*}{$\begin{array}{l}\text { Bol pri stajanju na mjestu postop. - Bol pri stajanju na } \\
\text { mjestu preop. }\end{array}$} & Negativni rangovi & $6^{\mathrm{a}}$ & 3,50 & 21,00 \\
\hline & Pozitivni rangovi & $0^{\mathrm{b}}$ & 0,00 & 0,00 \\
\hline & Jednako & $4^{c}$ & & \\
\hline & Ukupno & 10 & & \\
\hline \multirow{4}{*}{$\begin{array}{l}\text { Bol pri hodanju po ravnoj podlozi postop. - Bol pri } \\
\text { hodanju po ravnoj podlozi preop. }\end{array}$} & Negativni rangovi & $9^{a}$ & 5,00 & 45,00 \\
\hline & Pozitivni rangovi & $0^{\mathrm{b}}$ & 0,00 & 0,00 \\
\hline & Jednako & $1^{c}$ & & \\
\hline & Ukupno & 10 & & \\
\hline \multirow{4}{*}{$\begin{array}{l}\text { Bol pri hodanju uz stepenice postop. - Bol pri hodanju uz } \\
\text { stepenice preop. }\end{array}$} & Negativni rangovi & $8^{a}$ & 4,50 & 36,00 \\
\hline & Pozitivni rangovi & $0^{\mathrm{b}}$ & 0,00 & 0,00 \\
\hline & Jednako & $2^{c}$ & & \\
\hline & Ukupno & 10 & & \\
\hline \multirow{4}{*}{ Bol trbuha danas - Bol trbuha 1. postop. dan } & Negativni rangovi & $8^{a}$ & 4,50 & 36,00 \\
\hline & Pozitivni rangovi & $0^{\mathrm{b}}$ & 0,00 & 0,00 \\
\hline & Jednako & $2^{c}$ & & \\
\hline & Ukupno & 10 & & \\
\hline
\end{tabular}

a. Pokazatelj postop. < Pokazatelj preop.; b. Pokazatelj postop. > Pokazatelj preop.; c. Pokazatelj postop. = Pokazatelj preop.

Tablica 5. Funkcionalni postoperativni nalaz

\begin{tabular}{|l|c|c|}
\hline & Z & Asymp. Sig. (2-tailed) \\
\hline Oteklina postop. - Oteklina preop. & $-2,032^{\text {b }}$ & $\mathbf{0 , 0 4 2}$ \\
\hline Pokretljivost postop. - Pokretljivost preop. & $-1,769^{\text {c }}$ & 0,077 \\
\hline Bol pri ležanju postop. - Bol pri ležanju preop. & $-1,841^{\text {b }}$ & 0,066 \\
\hline Bol pri stajanju na mjestu postop. - Bol pri stajanju na mjestu preop. & $-2,232^{\text {b }}$ & $\mathbf{0 , 0 2 6}$ \\
\hline $\begin{array}{l}\text { Bol pri hodanju po ravnoj podlozi postop. - Bol pri hodanju po ravnoj podlozi } \\
\text { preop. }\end{array}$ & $-2,699^{\text {b }}$ & $\mathbf{0 , 0 0 7}$ \\
\hline Bol pri hodanju uz stepenice postop. - Bol pri hodanju uz stepenice preop. & $-2,530^{\text {b }}$ & $\mathbf{0 , 0 1 1}$ \\
\hline Bol trbuha danas - Bol trbuha 1. postop. dan & $-2,546^{\text {b }}$ & $\mathbf{0 , 0 1 1}$ \\
\hline
\end{tabular}

a. Wilcoxon Signed Ranks Test; b. Based on positive ranks; c. Based on negative ranks

dok je u 0 slučajeva zabilježen pozitivan rang, odnosno vrijednost odgovora na postoperacijskom testiranju veća je od vrijednosti odgovora na inicijalnom testiranju; najzad, u 2 slučaja zabilježena je jednaka vrijednost odgovora i za inicijalno i za postoperacijsko testiranje.
Uvidom u rangove za bol trbuha u 8 slučajeva zabilježen je negativan rang, odnosno vrijednost pokazatelja na postoperacijskom testiranju manja je od vrijednosti odgovora na inicijalnom testiranju, dok je u 0 slučajeva zabilježen pozitivan rang, odnosno vrijednost odgovora na postoperacij- 
skom testiranju veća je od vrijednosti odgovora na inicijalnom testiranju; najzad, u 2 slučaja zabilježena je jednaka vrijednost odgovora i za inicijalno i za postoperacijsko testiranje.

Signifikantnost testa $p$ iznosi manje od 0,05 $(p<$ $0,05)$ za oteklina, bol pri stajanju na mjestu, bol pri hodanju po ravnoj podlozi, bol pri hodanju uz stepenice, bol trbuha kod prvog i drugog mjerenja, što znači da odbacujemo nultu i prihvaćamo alternativnu hipotezu istraživanja, odnosno, može se reći, s razinom pouzdanosti od $95 \%$, kako je zabilježena statistički značajna razlika između prvog i drugog mjerenja za promatrane pokazatelje (tablica 5).

Pogleda li se razina signifikantnosti McNemar testa kod varijable svakodnevno uzimanje analgetika prije operacije, može se uočiti kako vrijednost signifikantnosti iznosi 0,125 ( $p>0,05)$, što znači kako nije uočena statistički značajna razlika s obzirom na svakodnevno uzimanje analgetika postoperacijski.

\section{RASPRAVA}

Osteoartritis je jedna od najčešćih bolesti zglobova širom svijeta u odraslih osoba. Liječili smo u našem istraživanju pacijente koji pate od osteoartritisa koljena s novom, jedinstvenom opcijom biološkog liječenja. ACPSVF kombinira regenerativni potencijal matičnih stanica iz masnog tkiva odrasle osobe uz dodatak plazme bogate trombocitima. Naši prvi rezultati mogli bi potvrditi obećavajući potencijal ove regenerativne metode za liječenje osteoartritisa. Sveukupno 10 pacijenata liječeno je ACPSVF-om, a oteklina, bol pri stajanju na mjestu, bol pri hodanju po ravnoj podlozi, bol pri hodanju uz stepenice, bol trbuha bili su značajno manji nego prije operacije.

Rezultate slične našima utvrdio je Mohsen ${ }^{21}$, koji je zabilježio bolju funkciju, povećanje hodne pruge i manju bolnost. Promjene je evidentirao i na poslijeoperacijskom MR-u koji mi nismo radili zbog kratkog vremena praćenja. Gibbs ${ }^{22}$ također navodi podjednak uspjeh u liječenju artroze koljena u početnoj fazi, dok su rezultati liječenja Hudetza ${ }^{23}$ i kolega bili nešto slabiji, prvenstveno jer se radilo o liječenju artroze u uznapredovaloj fazi bolesti.

Fodor $^{24}$ je u prva 3 mjeseca nakon operacijske procedure zabilježio značajno poboljšanje klinič- ke slike liječenih pacijenata, bez ikakvih komplikacija, ali na MR-u nisu primijećene nikakve promjene $u$ istom vremenskom periodu.

Pers ${ }^{25}$ u svom radu također ne navodi u jednogodišnjem praćenju niti jednu lokalnu ili sistemsku nuspojavu ili komplikaciju. Bol, hod, funkcijski status koljena značajno su se poboljšali u prvih pola godine, nakon čega dolazi do ponovne bolnosti i smanjenja hodne pruge. MRI rađen 6 mjeseci nakon procedure pokazuje zadebljanje hrskavičnog tkiva te smanjenje veličine edema subhondralne kosti u polovice ispitanika.

Orozco $^{26}$ je proučavajući liječenje OA-a koljena kod 12 pacijenata u trajanju godine dana ustanovio poboljšanje kliničkih parametara od 65 do $78 \%$, a na MR-u je uočio smanjenje degradirane hrskavice prosječno $27 \%$, uz poboljšanje hrskavičnog tkiva uopće.

Hudetz i sur. ${ }^{27}$, kao i Jo i sur. ${ }^{28}$ uočili su značajnije pogoršanje u pacijenata liječeni matičnim stanicama 2 godine nakon inicijalnog liječenja, a njih je Jo detektirao i na MR-u nakon 2 godine.

$\mathrm{Kim}^{29}$ proučavajući 203 pacijenta liječenih ovom metodom registrira samo značajnije smanjenje bolova u pacijenata, dok nikakve promjene nije registrirao na MR-u. Slično istraživanje proveo je isti autor na 220 pacijenata s istim zaključkom. Hong $^{30}$ navodi značajno bolje rezultate liječenja OA-a stromalnim stanicama nego primjenom preparata hijaluronske kiseline.

Unutar ovog kratkog vremena pacijenti su pokazali impresivno poboljšanje u usporedbi s njihovim početnim stanjem u svim kategorijama: bol, ukočenost i funkcija. Važno je da nismo utvrdili nuspojave za vrijeme ili nakon liječenja ACPSVF-om.

Dodatna prednost ACPSVF-a je potreba za manje masnog tkiva koje se mora sabrati u usporedbi s drugim sustavima. Pogotovo kod sportaša, koji obično imaju vrlo malo masnoće, ovo bi mogao biti značajan faktor. Nadalje, manje ozljeda tkiva uzrokovano je liposukcijom, a postupak pripreme je vrlo jednostavan i brz. Mi vjerujemo da je ACPSVF siguran i pruža mjerljive koristi za olakšavanje bola i funkcionalno poboljšanje u pogledu koljena OA-a.

\section{ZAKLJUČCI}

lako je naše istraživanje provedeno na malom broju ispitanika, a vrijeme praćenja bilo je relativ- 
no kratko, pacijenti su pokazali značajno funkcionalno poboljšanje kliničkih tegoba. Potrebna su daljnja istraživanja i praćenja kako bi se donijele smjernice u liječenju ovom metodom, dužim praćenjem i većim brojem ispitanika.

Izjava o sukobu interesa: Autori izjavljuju da ne postoji sukob interesa.

\section{LITERATURA}

1. Woolf $A D$, Pfleger B. Burden of major musculoskeletal conditions. Bull World Health Organ 2003;81:646-656.

2. Zhang W, Moskowitz RW, Nuki G, Abramson S, Altman $\mathrm{RD}$, Arden N, et al. OARSI recommendations for the management of hip and knee osteoarthritis, Part II: OARSI evidence-based, expert consensus guidelines. Osteoarthritis Cartilage 2008;16:137-162.

3. Felson DT. Developments in the clinical understanding of osteoarthritis. Arthritis Res Ther 2009;11:203.

4. Biswal S, Medhi B, Pandhi P. Longterm efficacy of topical nonsteroidal antiinflammatory drugs in knee osteoarthritis: meta-analysis of randomized placebo controlled clinical trials. J Rheumatol 2006;33:1841-44.

5. Clegg DO, Reda DJ, Harris CL, Klein MA, O'Dell JR, Hooper $\mathrm{MM}$, et al. Glucosamine, chondroitin sulfate, and the two in combination for painful knee osteoarthritis. N Engl J Med 2006;354:795-808.

6. Bellamy N, Campbell J, Robinson V, Gee T, Bourne R, Wells G. Intraarticular corticosteroid for treatment of osteoarthritis of the knee. Cochrane Database Syst Rev 2006;19:CD005328.7. Hogenmiller MS, Lozada CJ. An update on osteoarthritis therapeutics. Curr Opin Rheumatol 2006;18:256-60.

8. Hunter DJ, Le Graverand-Gastineau MP. How close are we to having structure-modifying drugs available? Rheum Dis Clin North Am 2008;34:789-802.

9. Brouwer RW, Raaij van TM, Bierma-Zeinstra SM, Verhagen AP, Jakma TS, Verhaar JA. Osteotomy for treating knee osteoarthritis. Cochrane Database Syst Rev 2007; CD004019.

10. Laupattarakasem $\mathrm{W}$, Laopaiboon $\mathrm{M}$, Laupattarakasem $\mathrm{P}$, Sumananont C. Arthroscopic debridement for knee osteoarthritis. Cochrane Database Syst Rev 2008; CD005118.

11. Lonner JH. A 57-year-old man with osteoarthritis of the knee. JAMA 2003;289:1016-25.

12. Pawan KG, Charan T. Mesenchymal stromal cells for the treatment of osteoarthritis of knee joint: context and perspective. Ann TransI Med 2019;7:S179.

13. Michalek,J, Vrablikova A, Darinskas A, Lukac Prucha, J, Skopalik J, Travnik J et al. Stromal vascular fraction cell therapy for osteoarthritis in elderly: Multicenter casecontrol study.J Clin Orthop Trauma 2019;10:76-80.

14. Filardo G, Kon E, Buda R. Platelet-rich plasma intra-articular knee injections for the treatment of degenerative cartilage lesions and osteoarthritis. Knee Surg Sports Traumatol Arthrosc 2011;19:528-35.

15. Lopa S, Colombini A, Moretti M, de Girolamo L. Injective mesenchymal stem cell-based treatments for knee osteoarthritis: from mechanisms of action to current clinical evidences. Knee Surg Sports Traumatol Arthrosc 2019; 27:2003-20.

16. Michalek J, Moster R, Lukac L. Stromal vascular fraction cells of adipose and connective tissue in patients with osteoarthritis: a case control prospective multi-centric non-randomized study. Global Surg 2017;3:1-9.

17. Pak J, Lee JH, Pak N. Cartilage regeneration in humans with adipose tissue-derived stem cells and adipose stromal vascular fraction cells: updated status. Int J Mol Sci 2018;23:19.

18. Bansa HI, Comella K, Leon J, Verma P, Agrawa D, Koka P et al. Intra-articular injection in the knee of adipose derived stromal cells (stromal vascular fraction) and platelet rich plasma for osteoarthritis. J Transl Med 2017; 15:141.

19. Pak J, Lee HH, Kwang Park KS, Park M, Kang LW, Lee SH. Current use of autologous adipose tissue-derived stromal vascular fraction cells for orthopedic applications. Journal of Biomedicine Science 2017;24:9.

20. Kohn MD, Sassoon AA, Navin D, Fernando, M. Classifications in Brief: Kellgren-Lawrence Classification of Osteoarthritis. Clin Orthop Relat Res 2016;474:1886-93.

21. Sheykhhasan M, Manoochehri H, Pourjafar M, Fayaz N. Mesenchymal stem cells as a valuable agent in osteoarthritis treatment.Stem Cell Investig 2018;5:41.

22. Gibbs N, Diamond R, Sekyere EO, Thomas WD. Management of knee osteoarthritis by combined stromal vascular fraction cell therapy, platelet-rich plasma, and musculoskeletal exercises: a case series. J Pain Res 2015;8:799-806.

23. Hudetz $D$, Borić $\mathrm{I}$, Rod E, Jeleč Ž, Kunovac B, Polašek $\mathrm{O}$ et al. Early results of intra-articular micro-fragmented lipoaspirate treatment in patients with late stages knee osteoarthritis: a prospective study. Croat Med J 2019;60: 227-36.

24. Fodor PB, Paulseth SG. Adipose Derived Stromal Cell (ADSC) Injections for Pain Management of Osteoarthritis in the Human Knee Joint. Aesthet Surg J 2016;36:229-36.

25. Pers YM, Rackwitz L, Ferreira R, Pullig O, Delfour C, Barry $F$, et al. Adipose Mesenchymal stromal cell-based therapy for severe osteoarthritis of the knee: a phase I doseescalation trial. Stem Cells Transl Med 2016;5:847-56.

26. Orozco L, Munar A, Soler R, Alberca M, Soler F, Huguet $M$ et al. Treatment of knee osteoarthritis with autologous mesenchymal stem cells: two-year follow-up results.Transplantation 2014;15:97.

27. Hudetz D, Borić I, Rod E, Jeleč Ž, Radić A, Vrdoljak T et al. The Effect of Intra-articular Injection of Autologous Microfragmented Fat Tissue on Proteoglycan Synthesis in Patients with Knee Osteoarthritis. Genes (Basel) 2017; 13:8.

28. Jo CH, Chai JW, Jeong EC, Oh S, Shin JS, Shim H et al. Intra-articular injection of mesenchymal stem cells for the treatment of osteoarthritis of the knee: a 2-year followup study. Am J Sports Med 2017;45:2774-83.

29. Kim SH, Ha CW, Park YB, Nam e, Lee JE, Lee HJ. Intra-articular injection of mesenchymal stem cells for clinical outcomes and cartilage repair in osteoarthritis of the knee: a meta-analysis of randomized controlled trials. Arch Orthop Trauma Surg 2019;139:971-80.

30. Hong HS, Kim DY, Yoon KJ, Son Y. A new paradigm for stem cell therapy: substance-P as a stem cell-stimulating agent. Arch Pharm Res 2011;34:2003-6. 